\title{
THEORY AND EXPERIENCES OF DIGITAL TV COVERAGE
}

Chair: José Frederico Rehme - Diretor da SET, Diretor da TVCI, professor da Universidade Positivo

The sucess of a DTV site project is proportional to the reception facilty and signal stability at the viewer's home. By the technical issue, it depends on de signal intensity and the $\mathrm{C} / \mathrm{N}$ ratio at the arrival's point. We will discuss the tools and the methods taken to achieve a good project: trustworthy, robust, accessible prices, simple. It will be explored the topics: prediction, analysis, measurement, density versus intensity, SFN and Gap Filler.

- THEORY AND PRACTICE OF DIGITAL TV COVERAGE Speaker: Marcello Martins - Diretor Executivo na iTVX do Brasil Com. e Serviços de Telecom Ltda

Evolution of the types of prediction tools; Block/functional diagrams, SFN and MFN coverage areas; Use and applications in DTV transmission and reception; 'Flying by instruments' .... with current frequency figures...

\section{GENERAL ASPECTS OF A DIGITAL TV PROJECT}

Speaker: Anderson de Oliveira - RPC Telecom Projects - Globo affiliate Paraná

Critical decision-making is necessary for the development of a Digital TV deployment project. The first is the choice of propagation model. The modeling is inserted as an element able to describe mathematically the behavior of the electromagnetic wave, as well as its losses. From this it is possible to establish coverage criteria, but are required analysis parameters of the same, to be chosen by the designer. Another aspect to be discussed is the importance of crossing the coverage data with field measurements. Finally, we will deal with the SFN network and gap-filler as a coverage optimization solution, with case studies.

\section{EVOLUTION OF PREDICTIONS FOR REGULATORY ASPECTS AND CONFRONTATION WITH FIELD MEASUREMENTS}


Speaker: Paulo Eduardo dos Reis Cardoso Doutorando / Especialista em Regulação Universidade Estadual de Campinas / Agência Nacional de Telecomunicações

Analysis of the predictions of coverage of broadcasting stations used for approval by Anatel. The Mosaico System. What should be observed (Field Intensity, SNR, MER, etc.) in the field evaluation of Digital TV stations. How to evaluate a SFN for Digital TV.

- RESOURCE OPTIMIZATION FOR TV COVERAGE: THE COSTEFFECTIVENESS AS A CRITERION FOR SETTING PARAMETERS Speaker: Luiz Ricardo Tonin - Coordinator of Broadcast Projects at SM Facilities

The choice of parameters to predict coverage are significant elements for the definition of TV network investments, since they define irradiance height, transmitter power and antenna models, with direct impacts on the feasibility of infrastructure deployment and operating costs. We will demonstrate real cases of projects considering these criteria and the results obtained and that can be replicated for the optimization of investments in this step of increasing the coverage of Digital TV.

- Speaker: Valderez De Almeida Donzelli - Director - ADTHEC Engenharia e Sistemas / SET

- ADVANCED ISDB-T SFN NETWORK PLANNING - CHALLENGES AND OPPORTUNITIES

Speaker: Milos PAVLOVIC - Sales Director Broadcast LS telcom AG, Germany

To be highly effective when conducting broadcast planning requires up-to date knowledge of latest trends and technologies. Detailed knowledge about the huge variety of planning functionalities is as important as information about the technologies themselves. This presentation will introduce to planners and broadcast engineers necessary requirements they need for the complex tasks of modern broadcast planning, such as ISDB-T SFN planning.

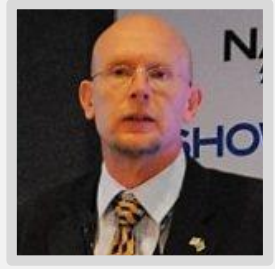

José Frederico Rehme - Diretor da SET, Diretor da TVCI, professor da Universidade Positivo

José Frederico Rehme is SET Teaching Director, Coordinator and Professor of the Electrical

Engineering and the Energy Engineering courses at Positivo University and Engineering Director at TVCi. 


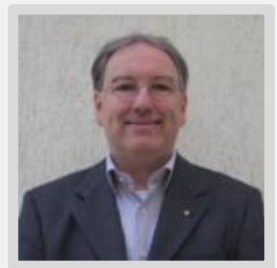

\section{Marcello Martins - Diretor Executivo na iTVX do Brasil Com. e Serviços de Telecom Ltda}

Holds a degree in Electronics Engineering, with Specialization in Telecommunications (1989) and Business Administration, graduate qualification with an MBA from USP/FIA and an extension qualification from Manchester Business School/England (2001). Specialization in satellite-based reception systems since 1982 and RF projects for terrestrial TV generators and repeaters. Began his career in the technical area at Tupi Radio e TV network in São Paulo/1978. In the 1980s, he decided to move into business, where for more than 28 years he has worked in Industry, Commerce and Engineering Services for new electronic products for HD digital reception. Currently executive Director at iTVX do Brasil Com. e Serviços de Telecom Ltda, a technical engineering projects company in the broadcasting and telecommunications field since 2008. Associate member of SET/Sociedade de Engenharia de TV, since 1986; associate member of the GESC, FEA/USP, social support since 2001, associate member of the Digital TV Forum, SBTVD (2010 to 2012).

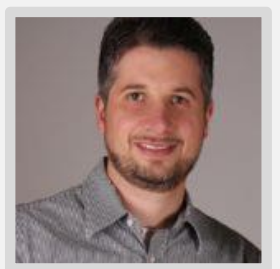

\section{Anderson de Oliveira - RPC Telecom Projects - Globo affiliate - Paraná}

Telecommunication Engineer by FURB Regional University Foundation of Blumenau Conclusion 2006, Graduate in Management of People in Organizations by UNIPLAC - University of Planalto Catarinense - Conclusion 2009, Post Graduation in Computer Networks and Convergent Services in the Positivo University. Prediction of Completion in 2017. He has been working for 11 years in the Projects sector, with 7 years in the Telecom Projects sector of RPC - Affiliate Globo in Paraná.

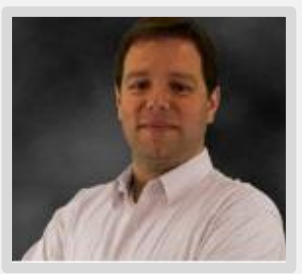

\section{Paulo Eduardo dos Reis Cardoso Doutorando / Especialista em Regulação Universidade Estadual de Campinas / Agência Nacional de Telecomunicações}

Holds a degree in Electrical Engineering from the FEEC-UNICAMP (2002) and a MSc degree in Electrical Engineering (Electronics) by DEMICFEEC-UNICAMP (2005). He is currently a PhD candidate in the LCVDECOM-FEEC-UNICAMP, searching Digital TV. Licensed from the post of Specialist in Regulating in the Anatel, where it operates in coordination of grants and resources to the provision, working with the licensing and amendment of technical characteristics of broadcasting stations. Previously, he served in the surveillance in broadcasters. He was responsible for the Technical Regulation to Broadcasting in Modulated Frequency and analysis of processes of technical feasibility for inclusion or amendment of the Basic Plan of Distribution Channels of Broadcasting in Modulated Frequency. He participated as an observer in the Federal Government in testing of Digital Radio Broadcasting, both in tests of American Standard - HD Radio, in 2008 and 2012, as in tests of the European standard - DRM, in 2010. He has worked as a telecommunications researcher of the Fundação Centro de Pesquisas e Desenvolvimento CPqD.

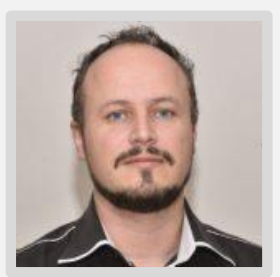

\section{Luiz Ricardo Tonin - Coordinator of Broadcast Projects at SM Facilities}

Luiz Ricardo Tonin is an electrical engineer graduated from Universidade Positivo and has 8 years of experience in the field of telecommunications engineering, with expertise in broadcasting, having worked in telephone and radio companies. He is currently Coordinator of Broadcast Projects at SM Facilities, an engineering company that provides technical, implementation and construction services to the broadcasting and telecommunications area. He is a specialist in prediction software and in transmission technician projects, he actively participates in the development of new solutions for the analog switch-off and the migration of the $700 \mathrm{MHz}$ band.. 


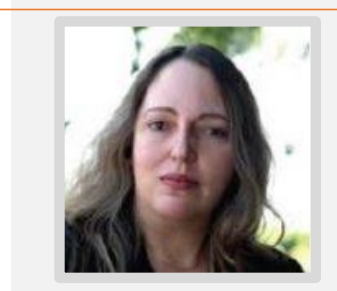

\section{Valderez De Almeida Donzelli- Director - ADTHEC Engenharia e Sistemas / SET}

Holds a degree from the industrial school of engineering (FEI) in electronic engineering, power engineering and production. She obtained a Master's in electrical engineering, defending the dissertation "Polarização Elíptica: Influência no desempenho de cobertura da TV Digital" (free translation, Elliptical Polarization: Its influence on the coverage performance of Digital TV", and is reading for her doctorate with the survey "TV Digital: Disponibilidade de Sinal" (free translation, Digital TV: Signal Coverage), both from the Mackenzie University. She also holds a specialization in IT from FESP, ICT management from the FGV and Advanced Digital TV Systems, from INATEL. Technical Director of ADTHEC (www.adthec.com.br), a company offering consultancy, planning, design, research and analysis of risks and solutions for public and private sector radio, television and telecommunications stations, with the emphasis on the design and installation of digital and FM transmission systems. She actively participates in a range of Brazilian and international working groups under the coordination of Anatel, the Ministry of Communications, Universities, Associations and Research Centers. She began her professional activities in bio-engineering at the Heart Institute of the Clinics Hospital, lectured at the FAAP and worked for over years in several departments of the Padre Anchieta Foundation (Cultura TV and Radio, in São Paulo). In charge of the technical projects division, she coordinated the design and planning of the TV and radio network, testing and implementing new technologies, while managing the relations with prefectures, broadcasters, the Ministry of Communications and Anatel. She has headed up studies, tests and measurements involving the systems for implementing digital TV in Brazil, as well as the group that reviewed the regulations for sound and picture broadcasting services. She is currently deputy director for education and member of the editorial committee of SET, where she has also held the position of relationship and editorial director.

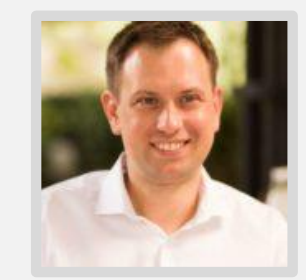

\section{Milos PAVLOVIC - Sales Director Broadcast LS telcom AG, Germany}

Milos Pavlovic has a diploma in Electrical Engineering/Telecommunications. He received his DIpl. Ing and MSc degrees from University of Belgrade, Faculty for Electrical Engineering. Milos has been in the Sales \& Marketing department of LS telcom AG since 2012, with more than 10 years of experience working in the broadcast industry. After joining LS telcom, he has taken over the responsibility for its broadcast customers globally. 